\title{
Poverty Coping Strategies of Rural Women Dwellers of Batagarawa Local Government Area of Katsina State, Nigeria
}

\author{
Dr. Iyela $A^{1}$ \\ Dr. Ikwuakam O.T2 \\ 1. Federal College of Education, Okene. PMB 1026 Okene, Kogi State \\ 2. Federal College of Education, Katsina, PMB 2041 Katsina, katsina State Email: ikwuosca@yahoo.com
}

\section{Doi:10.5901/mjss.2015.v6n6s4p296}

\section{Abstract}

Rural poverty has been the bane of many developing countries including Nigeria and rural women dwellers are often among the vulnerable groups to its consequences. The study determined poverty coping strategies of rural women dwellers of Batagarawa Local Government Area (LGA) of Katsina State, Nigeria. Simple random sampling technique was used to sample 10 rural women from each of the 6 selected villages to give a sample size of 60 women that was used for the study. A structured interview schedule containing questions on respondents' socio-economic characteristics, coping strategies and constraints was used to collect data. Descriptive statistics such as frequency counts, percentages, and means were used to describe the data while Chi square and PPMC were used to determine the relationship between the independent variables and dependent variable. Women in the area were mostly married (80\%), Muslims (88.3\%), members of women group (66.7\%) with mean age of (28.8 \pm 8.39 ), farm size (2.9 \pm 1.52$)$, experience (12.8 \pm 6.76$)$ and had Quranic education (80\%). Processing of farm produce $(\bar{x}=2.23)$, sale of farm produce $(\bar{x}=1.87)$ ranked $1{ }^{\text {st }}$ and $2^{\text {nd }}$ among non-agricultural coping strategies while rabbitary ( $\bar{x}=2.13)$ and poultry production $(\bar{x}=2.03)$ were ranked 1 st and $2^{\text {nd }}$ agricultural based coping strategies. Also levels of use of both non-agricultural (53.3\%) and agricultural (53.3\%) coping strategies were high. Lack of access to credit $(\bar{x}=1.67)$ and finance $(\bar{x}=1.60)$ ranked $1^{\text {st }}$ and $2^{\text {nd }}$ among constraints faced by women in the use of the coping strategies. Significant

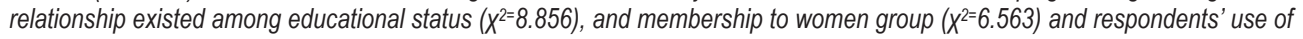
non- agricultural coping strategies while women group $\left(X^{2}=8.929\right)$ was significantly related with respondents' uptake of agricultural based coping strategies. Also farm size $(r=-0.276)$, experience $(r=0.381)$, and constraints $(r=-0.394)$ significantly correlated with respondents' level of use of both non-agricultural and agricultural coping strategies. Level of poverty coping strategies of the respondents was high. A policy framework by the government targeted at reducing or obliterating the bureaucratic principles that create barriers to rural women's access to bank credit or any other sources is germane.

Keywords: Poverty, non-agricultural based coping strategies, agricultural based coping strategies, rural women dwellers, constraints.

\section{Introduction}

That poverty is a reality and spreading like wild fire in recent times especially in developing countries is no more in doubt. Also not in contention is the worldwide outrage on poverty as many people the world over are reportedly living in absolute poverty and suffer from chronic hunger (Simpa 2014). The rural areas seem to be the worst hit going by the report of Simpa (2014) that about 3.1 billion people (55\%) in rural areas are poor with about 1.4 billion living in less than US \$1.25. Okunmadewa (2005) further noted that life for most people today is a matter of daily struggle for survival. The same source observed that ill health, illiteracy and degraded environment are forces that the poor battle on regular basis. Sen (1989) along this line had considered poverty as the absence of some basic capabilities to function and the denial of opportunities.

The situation as it is Nigeria is particularly worrisome. The study of Okunmadewa (2005) buttressed that in 2001, close to $70 \%$ of the citizens were living below the poverty line. Such a precarious social scenario is relatively high among rural Nigerian populace and this is based on national poverty survey which indicated that the high tropic areas have moderate poverty while the northern regions have a 60\% high level of poverty (Apata and Apata 2010; Okunmadewe, Yusuf, Omonona, 2005; NBS, 2009). The National Bureau of Statistics (2010) further revealed that five northern states (Sokoto (86\%), Bauchi (83.7\%), Katsina (82.0\%), Adamawa (80.7\%) and Kebbi with 80.5\%) have record of poorest people in Nigeria. Okunmadewe (2005) earlier stated that Nigeria, like other sub-Saharan African countries has a phenomenal rural poverty that is more pronounced in the northern part of the country, with pockets of severity in the 
riverine and remote southern areas. Generally, however, Francis (1999) as reported in Olawoye (2003) found out that "a characteristic of the distribution of poverty in Nigeria is the concentration of the poor in communities where most of the population of the poor ....nearly $80 \%$ resides and in which the average per capita expenditure was below the national median".

The situation has invariably made the socio-economic environment of Nigeria squalid. The unfavorable socioeconomic climate in the country is evidenced by different dimensions of social vices (violence, crimes, ethnic clashes and insecurity) that have over the years ravaged Nigeria. Also prevalent are pervasive unemployment, low wages and limited opportunities, income and low returns from investment. Related to this is World Bank, (2010) observation that "given that poverty level is determined by availability or non-availability of requisite resources that guarantee good living, maintain good health and physical efficiency, food, clothing, shelter, education, security, leisure and recreation, one may hold at nothing in concluding that Nigeria's scenario is rife. This is more revealing in the nation's drop in human development index from 129 in 1990 to 159 in 2003 out of 177 countries as reported by Etim and Edet, (2007), World Bank, (2007) in Simpa (2014).

Another interesting aspect of poverty is that rural women are reportedly more vulnerable accounting for $70 \%$ of the poor (Moghadam, 2005) even when it is not gender exclusive. This may be attributed to gender inequalities and women's inadequate access to pecuniary profitable assets that can enable them provide their basic needs. The situation however, has attracted poverty reduction interventions/activities and programmes of various national and international organizations and governments. These include that of the United State Agency for International Development (USAID), Department for International Development (DFID), and the UN group (Okunmadewe, 2005) The same source revealed that UN system also established a collaborative team that comprised of UNDP, UNICEF, ILO, WHO, FAO, and the World Bank as the lead agency in order to achieve its mandate of poverty reduction in Nigeria. Also in the chase was the Federal Government's National Poverty Eradication programme (NAPEP) that was targeted at absolute eradication of poverty among the people of Nigeria (Olawoye, 2003). Olawoye (2003) further revealed that with NAPEP, Nigerians were to have steady source of real income, high purchasing power, abundant quality and high nutritional food, basic health facilities, good education, drinking water, good housing units, quality roads and other means of transportation, affordable power, cheap and affordable quality consumer products, congenial environment for production and provision of quality services. Unfortunately, Vincent, (2006) has identified continued inadequate financial and human resources, debt burden, time constraint associated with women's fulfillment of their multiple roles, war and civil strife as constraints to poverty reduction efforts. This is to say that socio-economic inequalities have remained the bane of Nigeria. It implies succinctly that the end to poverty, hunger; malnutrition and associated diseases in Africa and Nigeria in particular are not in sight. One therefore wonders whether the measures/actions by the various stakeholders were actually germane to poverty mitigation or in effect exacerbated or perpetuated existing socio-economic inequalities in the country.

In the midst of such uncertainties, adoption of diverse coping mechanisms have often times being a formidable mitigating force available to people. Defined as a sum total of ways in which one deals with minor to major stress and trauma (Webster New World Dictionary 1984), coping strategy may vary from place to place and among individuals. This is to say that the ability of a people to break out of poverty or adopt a coping mechanism is often associated with the peculiarities of the conditions within their communities. In South eastern Nigeria, for example, the coping mechanisms of rural women were found to include domestic work, crop processing, trading, as well as gathering of forest products and certain farming operations on their own or husbands' farm (UN, 1980). Others are petty trading, craft, weaving, carving, and hired causal labor (Edeoghon \& Koyenikan 2010). Given that people's coping strategies could vary from one location to another even among individuals depending on their poverty levels and dispositions, investigating those of rural women dwellers in Batagarawa Local Government Area of Katsina State is germane.

\section{Study Objectives}

The specific objectives of the study are to:

1. Examine the socio-economic characteristics of the respondents

2. determine the poverty coping strategies of the respondents

3. Identify respondents' constraints to coping strategies

\section{Hypothesis}

1. There is no significant relationship between the socio-economic characteristics of the respondents and their level of poverty coping strategies. 


\section{Literature Review}

Poverty (i.e. lack of basic necessities such as food, clothing, shelter, medical care and safety) by many is becoming wild spread across the world. This opinion is strengthened by Omoniyi (2012) who described poverty as a global phenomenon. Similarly, whereas; Anyanwu, (1997) explained poverty to include various forms of alienations and deprivations such as: lack of human capabilities, poor life expectancy, poor maternal health, illiteracy, poor nutritional levels, poor access to safe drinking water and perceptions of well-being, World Bank Report (1990, 1999 and 2005) defined it as involving both physiological and social deprivations, vulnerability, inequality and violation of basic human rights, inability of certain persons to attain a minimum standard of living and a state of powerlessness, lack of representation and freedom.

Today, about 1.2 billion people are reportedly living in extreme poverty less than one dollar per day the world over (Omoniyi 2012) with the situation becoming increasingly a major source of worry to both national and international agencies and government. In Africa, World Bank Report (2000) described over 200 million people as wallowing in abject poverty while an average of 45 to $50 \%$ of sub-Saharan Africans live below the international poverty line of one American dollar a day. Omoniyi (2012) also noted that though the developed world seems to have made significant effort in poverty reduction, such cannot be said of sub-Saharan Africa. The previous studies of Ayoola, Aina, Mamman, Nweze, Odebiyi, Okunmadewa, Shehu, Williams, Zasha, (2000); Okunmadewa (2002); Alayande and Alayande, (2004), have shown that in Africa, sub-Saharan is the poorest region in Africa and they depend highly on agriculture as their primary source of food and income. For example Mozambique is ranked165 of 169 countries of the Human Development Index (World Bank, 2009). Empirical evidences on the existence of poverty trap in Honduras and Ethiopia have also been revealed by (Carter, Little, Mogues, and Negatu, (2007); Adato, Carter, and May 2006; Barrett, Marenya, Mcpeak, Minten, Murithi, Oluoch-Kosura, Place, Randrianarisoa, Rasambainarivo and Wangila, 2006; Lybbert, Barrett, Desta, and Coppock 2004). In the same vein countries like Uganda, Mali, Nigeria, Zambia, Niger, Madagascar, Zimbabwe, Burundi and Rwanda are also having more than 50 percent of their population living below \$ 1 a day in 2002 (Addae-Korankye 2014).

Nigeria's situation has been described as a paradox (Omoniyi 2012 and Asogwa (2012) given the country's enormous human and materials resources. Tracing the trend in Nigeria, Ekpe (2011) noted a retrogressed ranking of Nigeria as one of the 25 poorest countries in the world while the 2010 poverty index indicated $60.9 \%$ Nigerians as regrettably living in absolute poverty (Baba-Ahmed 2012). Omoniyi (2012) again stated that the proportion of the population living below the poverty line has continued to increase. This opinion is strengthened by the trend analysis of National Bureau of Statistics (NBS) (2012) which revealed a national relative poverty level of $28.1 \%, 46.3 \%, 42.7 \%$, $65.6 \%, 54.4 \%$ and $69 \%$ in 1980, 1985, 1992, 1996, 2004 and 2010 respectively. Added to this was the worrisome nature of rural poverty which NBS (2012) revealed to be high with $73 \%$ against $61 \%$ poverty incidence in the urban areas.

The rural populace is the worst hit and this is evidenced by the backwardness, bad road, women and children walking barefooted and trekking long distances to get water and firewood, pupils studying under trees, dilapidated and ill equipped health centers, lack of facilities and natural disasters, crime and violence that characterize most rural areas in Nigeria (Omoniyi 2012). Okunmadewa (2005) corroborated that violence, crime, ethnic clashes and insecurity, pervasive unemployment, low wages, and limited opportunities are the ugly faces of poverty.

It is also reported however, that all over the world, women are at the center of poverty. Hunter-Gault (2006) buttressed that the open secret about poverty in Africa is that it has a woman's face. Women in rural areas are hit hardest by poverty with the burden of being the backbone of the rural economies, farming small plots, selling fruits and vegetables and providing the basic necessities for their families; often times traveling long distances to the markets via dirt roads that are largely impassable, especially during long rainy seasons (Hunter-Gault 2006). What this implies is that when possibly the yardstick to measure the degree of people's poverty is their level of well-being, women are traditionally found to be more impoverished than men and this accounts for a disturbing global trend. Nigeria with an estimated population of over 140 million people and where nearly over 68 million (about 49\%) are women (Nigeria Observer 2014) is now noted for feminization of poverty that is not different from other sub-Saharan African countries. The reality is that Nigerian women are poor than their male counterparts. The findings of Oluwatoyin (2013) have also buttressed the feminization of poverty in Nigeria and a country in which most women population live below the poverty line. Heyzer (1992) as quoted by Adereti (2005) also stated that while both men and women suffer the ugly effects of being poor, women's experience of poverty is different and usually severe due to gender based form of exclusion. Maina (2013) further confirmed that an estimated $70 \%$ of Nigerian women are living below poverty line. The negative effects of the situation are enormous and rural women as a result face substantial idiosyncratic and covariant risks.

Mahogadam, (2005) as reported by Oluwatayo (2014) found some of the negative effects of poverty on the female gender to include involvement of women and children in the informal economy; differential treatment of girls and boys in 
households; pressure to get girls married off quickly; higher school drop-out rates for girls; less control over fertility; and recourse to prostitution.

Consequent upon this however, successive governments in Nigeria, had since mid 70's initiated specific multidimensional and multi-faceted programs in response to the scourging wave of poverty. Jibowo and Ajayi (2011) listed these efforts to included amongst others the National Accelerated Food Production Project (NAFPP) in 1972, the Agricultural Development Projects (ADP) in 1975, the Operation Feed the Nation Programme (OFN) in 1976 the Green Revolution programme in 1980, the Accelerated Development Area Project (ADAP) in 1982 and Multi-State Agricultural Development Projects (MSADP) in 1986. Others were the River Basin Development Authority (RBDA) in 1986, the Directorate of Food, Roads and Rural Infrastructure (DFRRI) in 1986, the National Directorate of Employment (NDE) in 1986 and the National Fadama Project (NFDP) in 1992. In recent years also, the Poverty Alleviation Programme (PAP) of 2000, the National Special programme for Food Security (NSPFS and the National Economic and Empowerment Development (NEEDS) in 2004 were introduced. Today, these initiatives that emphasized on employment creation, self reliance, increased productivity and improvement in people's welfare cannot be adjudged as having achieved their distinctive mandates successfully as number of poor Nigerians has continued to increase. UNDP Nigeria (1998), FOS, (1999) and Obadan (2002) attested to the increasing incidence of poverty in spite of the initiatives, suggesting that they were ineffective.

Available evidence also shows that in an effort to cope with the scourge of poverty, women particularly have adopted all forms of strategies. For example, Murray, Little, Hayloor, Felsing, Gowing, and Kodithuwakku (2001) as quoted by Akeweta, Oyesola, Ndaghu and Ademola (2014) reported that women engage in labor intensive work like crop cultivation, livestock rearing, fishing, agro-processing, petty trading, net making, mat weaving, food preparation, rice pounding and dress making coping mechanisms to poverty. The fact also remains that their children, when faced with daily reality of hunger often end up in the street pilfering, doing odd jobs, carry loads in the markets, hawking and begging with the teenage girls even resorting to prostitution. Such are part of their behavioral strategies to escape their ugly consequences of poverty.

Although, these behavioral responses or strategies to either cope, escape or reduce and manage the consequences of poverty may vary, the fact remains that rural poor women are often forced to adopt one type of coping mechanism or the other at a time to enable them survive in their distinctive communities. Coping strategy is the sum total of ways in which one deals with minor to major stress and trauma (Webster New World Dictionary 1984). It consists of those implicit principles that guide the poor when seeking goods and services to cope with a prevailing poor life situation. Edeoghon \& Koyenikan (2010) stated that while some of the processes are unconscious, others are learned. The report of Edeoghon \& Koyenikan (2010) further noted that not all coping strategies are beneficial but some may be very detrimental in effect. However, (Adereti 2005) listed some of the poverty coping strategies employed by both rural and urban dwellers to include buying food on credit, skipping food, eating unconventional foods such as yam peals and long period of breast feeding. Others include taking children out of school in order to have them employed in the wage labour market or at home.

\section{Methodology}

The study was carried out in Batagarawa Local Government Area (LGA) of Katsina State. The LGA has 17 villages which include: Ajiwa, Bakiyawa, Barawa, Batagarawa, Dan Iyan, Dandagoro,Danna Baso, Jino, Kaukai, Kayauki, Tsanni, YanRakumma, Barhim, Danbaibayawa, Rahaji, Tafkin almu, Makurda Using simple random sampling technique, 6(35\%) of the 17 villages were selected. The six villages included: Ajiwa, Dandagoro, Tsanni, Danbaibayawa, Kayauki, and Jino. Ten (10) women randomly sampled from each of the 6 selected villages and this resulted into a sample size of 60 women that was used for the study.

A structured interview schedule containing questions on respondents' socio-economic characteristics, coping strategies and constraints to coping strategies was used to collect data for the study. The poverty coping strategies of the respondents were measured on a 4 - point Likert type of scale of always (3), occasionally (2) rarely (1), Never (0). The mean score was determined and used to categorize respondents into high (scores of mean and above mean) and low (for scores below mean) in terms of level of coping strategies.

The constraints to coping strategies were also measured on a 4 - point Likert scale of very severe (3), severe (2), not severe (1) and not a constraint (0). Each respondent's score was obtained based on the constraints faced and the level of severity of such constraints. A total score was determined and respondents who scored below the mean value had low constraints, while those whose score equal or greater that the mean score had high level of constraints to poverty coping strategies. Descriptive statistics such as frequency counts, percentages, and means were used to 
describe the data while Chi square and PPMC were used to determine the relationship between the independent variables and dependent variable.

\section{Results and Discussions}

\subsection{Socio-economic characteristics of the respondents}

Table 1 presents data on the socio-economic characteristics of the respondents. It reveals that majority (40\%) were between 21-30 years with a mean age of 28.75 years. This implies that the respondents were within their active and productive ages and could be more desirous in changing their poor status. Adereti (2005) had earlier found rural women of Osun to be within their active productive age of 24 years. On household size, $48.3 \%$ have large household size of 1115 with mean household size of 8.78. This means availability of cheap household labour for increased coping activities. The result is consistent with that of Ironkwe, Asiedu, Chinaka and Ezebuiro (2008) in Abia State, Nigeria. The finding also revealed that majority (80\%) were married. This implies that early marriage is prevalent in the area. However, the respondents cultivated small plots of land which ranged between 1-2 hectares. The implication is that the women are small scale farmers. The result agrees with the finding of Ironkwe et al (2008) that women in Ohafia and Umuahia zones cultivated on small plots of land. Literacy level was abysmally low as $80 \%$ have Quaranic education while $6.7 \%$ have formal secondary school education. The means that opportunities opened to rural women with respect to education is low and could cause them to lack basic flexible skills that are germane to participate in more vibrant and result oriented coping strategies. Thus rural women in the area will be at increasing risk of being poor and falling behind men in most developmental issues. The finding contradicts that of Ezebuiro, Ironkwe, Ugboaja and Okoro (2010) on women farmers in Abia State. Majority (30\%) have between 11-15 years of farming experience. This is expected as the major occupation in most rural communities is farming and one begins to get involved and participate at the early stage of life. Respondents' year farming experience was found. The result further showed that $88.3 \%$ were Muslims while $11.7 \%$ were Christians. This finding may account to a greater extent in the determination of the activities the respondents can engage themselves to cope with poverty. The rural Muslim women in 'Purdah' may not be allowed to involve themselves in certain agricultural activities (Adereti 2005) and this may explain why majority (50\%) were mainly involved in poultry production (50\%) as agricultural coping strategy. Membership to group association was found to be high while that of cooperative association was low. The results indicated that while $66.7 \%$ of them were members of group association $75 \%$ never involved in cooperative societies. This implies that while majority may use their group associations to cope with poverty, same cannot be said of cooperative societies. The finding is in conformity with that of (Ironkwe et al 2008) and contradicts the earlier finding of Yahaya and Olowu (1998) that women farmers were members of various cooperative societies. Majority (91.7\%) practiced mixed farming on farm land sourced mainly from their husbands (76.7\%). It can be deduced from this finding that women in the area don't own land and may have limited access to self purchase of land for farming. However, while the type of farming practiced is in consonant with the finding of Duyilemi, Adegbite, Abiola and Onawumi (2008), result on source of land does not agree with Duyilemi, et al (2008) that most women in Oyo acquire their land through hire/lease rather than their husbands.

Table 1: Distribution of respondents on socio-economic characteristics

\begin{tabular}{|c|c|c|c|}
\hline Variable & $F$ & $\%$ & Mean \\
\hline \multicolumn{4}{|l|}{ Age (in years) } \\
\hline Less or equal 20 & 14 & 23.3 & $28.75 \pm 8.39$ \\
\hline 21-30 & 24 & 40.0 & \\
\hline $31-40$ & 18 & 30.0 & \\
\hline $41-50$ & 4 & 6.7 & \\
\hline \multicolumn{4}{|l|}{ Household size } \\
\hline $1-5$ & 13 & 21.7 & $8.78 \pm 4.70$ \\
\hline $6-10$ & 29 & 48.3 & \\
\hline $11-15$ & 14 & 23.3 & \\
\hline $16-20$ & 2 & 3.3 & \\
\hline Above 20 & 2 & 3.3 & \\
\hline \multicolumn{4}{|c|}{ Farm size/ enterprise size } \\
\hline $1-2$ & 29 & 48.3 & $2.88 \pm 1.52$ \\
\hline $3-4$ & 20 & 33.3 & \\
\hline $5-6$ & 11 & 18.3 & \\
\hline & & & \\
\hline
\end{tabular}




\begin{tabular}{|c|c|c|c|}
\hline \multicolumn{4}{|l|}{ Marital status } \\
\hline Married & 48 & 80.0 & \\
\hline Single & 2 & 3.3 & \\
\hline Divorced & 4 & 6.7 & \\
\hline Widowed & 6 & 10.0 & \\
\hline \multicolumn{4}{|l|}{ Educational qualification } \\
\hline No formal education & 4 & 6.7 & \\
\hline Quaranic & 48 & 80.0 & \\
\hline Primary & 4 & 6.7 & \\
\hline Secondary & 4 & 6.7 & \\
\hline \multicolumn{4}{|l|}{ Religion } \\
\hline Christianity & 7 & 11.7 & \\
\hline Islam & 53 & 88.3 & \\
\hline \multicolumn{4}{|l|}{ Traditionalist } \\
\hline \multicolumn{4}{|l|}{ Farm/enterprise experience } \\
\hline $1-5$ & 9 & 15.0 & $12.77 \pm 6.76$ \\
\hline $6-10$ & 16 & 26.7 & \\
\hline $11-15$ & 18 & 30.0 & \\
\hline $16-20$ & 5 & 8.3 & \\
\hline $21-25$ & 12 & 20.0 & \\
\hline \multicolumn{4}{|l|}{ Membership of co-operative society } \\
\hline No & 45 & 75.0 & \\
\hline Yes & 15 & 25.0 & \\
\hline \multicolumn{4}{|l|}{ Membership of women group } \\
\hline No & 20 & 33.3 & \\
\hline Yes & 40 & 66.7 & \\
\hline \multicolumn{4}{|l|}{ Cropping system practiced } \\
\hline Mono cropping & & 8.3 & \\
\hline Mixed cropping & 55 & 91.7 & \\
\hline \multicolumn{4}{|l|}{ Source of farmland } \\
\hline Communal & 2 & 3.3 & \\
\hline Husband & 46 & 76.7 & \\
\hline Personal & 12 & 20.0 & \\
\hline
\end{tabular}

Source: Field survey 2015

In order to ascertain respondents' non-agricultural and agricultural based coping strategies, the respondents were requested to score the items as always, occasionally, rarely and never used strategy. The results of the study as indicated in Table 2 show that respondents always engaged in petty trading (45.0\%) and occasionally process of farm products $(60 \%)$, sale of farm produce $(41.7 \%)$, gifts from family members $(68.3 \%)$, personal savings $(41.7 \%)$ and divine intervention (28.3\%), gifts from friends (48.3\%), and plaiting of hair (53.3\%). The result further revealed that purchasing food on credit (56.7\%), loan from local money lenders (87\%) and credit from cooperative society (78.3\%), selling of personal assets (66.7\%) and selling of firewood (90\%) were coping strategies the respondents never explored. However, processing of farm products $(\bar{x}=2.23)$ ranked $1^{\text {st }}$ among non-agricultural coping strategies of the respondents. This was followed by selling of produce ( $\bar{x}=1.87)$, gift from family members $(\bar{x} 1.78)$, and personal savings $(\bar{x}=1.60)$ that ranked $2^{\text {nd }}, 3^{\text {rd }}$, and $4^{\text {th }}$ respectively. This implies that these off farm activities are more profitable in income generation and effective in enabling the respondents cope with poverty. The findings do not agree with that of Edeoghon and Koyennikan (2010) except in the area of produce selling.

On the other hand, vegetable production (41.7\%) and poultry production (50\%) were the agricultural activities the respondents carried out always to cope with poverty with poverty. Also rabbit production (71.7\%), on farm crop processing (51.7\%) and gathering of forest produce (455\%) were occasionally undertaken by the respondents. Majority (98.3\%, 93.3\% and 100\% however, never indulged in bee keeping, grass cutter and fish farming. Rabbit production ( $\bar{x}=$ 2.13) was number one poverty coping activity of the respondents while poultry production $(\bar{x}=2.03)$, and gathering of forest produce $(\bar{x}=1.96)$ ranked $2^{\text {nd }}$ and $3^{\text {rd }}$ respectively as poverty coping activities of the respondents. The result means that the activities though, common trend in most rural areas have monetary gain to palliate poverty and pay at least children's schools, medication, and consumer goods. The finding is line with that of Janowski (2003) women from both female and male-headed households in the rural village of Letlhakane were engaged in subsistence agriculture in the form of small vegetable gardens growing maize, beans, melons, tomatoes, cabbages, onions, carrots, spinach, fruit trees 
and keeping livestock (goats) and domestic animals (poultry).

Table 2: Distribution of respondents on coping strategies

\begin{tabular}{|c|c|c|c|c|c|c|}
\hline Variables & Always & Occasionally & Rarely & Never & Mean & Rank \\
\hline Non-agricultural based activities: & $\mathbf{F}$ & $\mathrm{F}$ & $\mathbf{F}$ & $\mathrm{F}$ & & \\
\hline Gift from family members & 7(11.7) & $41(68.3)$ & $4(6.7)$ & $8(13.3)$ & 1.78 & $3^{\text {rd }}$ \\
\hline Gifts from friends & $1(1.7)$ & $29(48.3)$ & $6(10.0)$ & $24(40.0)$ & 1.12 & $6^{\text {th }}$ \\
\hline Credit from Bank & $1(1.7)$ & $0(0.00)$ & $0(0.00)$ & $59(98.3)$ & 0.05 & $19^{\text {th }}$ \\
\hline Purchasing food on credit & $0(0.00)$ & $21(35.0)$ & $5(8.30$ & $34(56.7)$ & 0.78 & $10^{\text {th }}$ \\
\hline Loan from local lenders & $1(1.7)$ & $5(8.3)$ & $3(5.0$ & $51(85.0)$ & 0.27 & $17^{\text {th }}$ \\
\hline Personal savings & $13(21.7)$ & $25(41.7)$ & $7(11.7)$ & $15(25.0)$ & 1.60 & $4^{\text {th }}$ \\
\hline Credit from women group & $1(1.7)$ & $25(41.7)$ & $4(6.7)$ & $30(50.0)$ & 0.95 & $9^{\text {th }}$ \\
\hline Credit from cooperative & $2(3.3)$ & $9(15.0)$ & $2(3.3)$ & $47(78.3)$ & 0.43 & $15^{\text {th }}$ \\
\hline Divine intervention & $16(26.7)$ & $17(28.3)$ & $6(10.0)$ & $21(35.0)$ & 1.47 & $5^{\text {th }}$ \\
\hline Skipping meals & $0(0.00)$ & $20(33.3)$ & $2(3.3)$ & $38(63.3)$ & 0.70 & $11^{\text {th }}$ \\
\hline New marketing channels & $4(6.7)$ & $6(10.0)$ & $3(5.0)$ & $47(78.3)$ & 0.45 & $14^{\text {th }}$ \\
\hline Withdrawing children from & $7(11.7)$ & $12(20.0)$ & $2(3.3)$ & $39(65.0)$ & 0.78 & $10^{\text {th }}$ \\
\hline Selling farm produce & $5(8.3)$ & $25(41.7)$ & $6(10.0)$ & $24(40.0)$ & 1.87 & $2^{\text {nd }}$ \\
\hline Petty trading & $27(45.0)$ & $12(20.0)$ & $7(11.7)$ & $14(23.3)$ & 0.57 & $13^{\text {th }}$ \\
\hline Selling of firewood & $3(5.0)$ & $2(3.3)$ & $1(1.7)$ & $54(90.0$ & 0.23 & $18^{\text {th }}$ \\
\hline Plaiting of hair & $12(20.0)$ & $14(23.3)$ & $2(3.3)$ & $32(53.3)$ & 1.10 & $7^{\text {th }}$ \\
\hline Selling of personal assets & $0(0.00)$ & $16(26.7)$ & $4(6.7)$ & $40(66.7)$ & 0.60 & $12^{\text {th }}$ \\
\hline Weaving & $3(5.0)$ & $15(25.0)$ & $3(5.0)$ & $39(65.0)$ & 0.70 & $11^{\text {th }}$ \\
\hline Causal labourer & $2(3.3)$ & $3(5.0)$ & $8(13.3)$ & $47(78.3)$ & 0.33 & $16^{\text {th }}$ \\
\hline Catering & $6(10.0)$ & $17(28.3)$ & $6(10.0)$ & $31(51.7)$ & 0.97 & $8^{\text {th }}$ \\
\hline Processing of farm products & $19(31.7)$ & $36(60.0)$ & $5(8.3)$ & $0(0.00)$ & 2.23 & $1^{\text {st }}$ \\
\hline \multicolumn{7}{|l|}{ Agricultural based activities: } \\
\hline Vegetable farming & $25(41.7)$ & 23(38.3) & $1(1.7)$ & $11(18.3)$ & 0.00 & $9^{\text {th }}$ \\
\hline Poultry & $30(50.0)$ & & $2(3.3)$ & $10(16.7)$ & 2.03 & $2^{\text {nd }}$ \\
\hline Rabbit & $43(71.7)$ & $12(20.0$ & $5(8.3)$ & $0(0.00$ & 2.13 & $1^{\text {st }}$ \\
\hline Selling of farm waste & $9(15.0)$ & $26(43.3)$ & $3(5.0)$ & $22(36.7)$ & 0.48 & $6^{\text {th }}$ \\
\hline Grass cutter production & $1(1.7)$ & $3(5.0)$ & $0(0.00)$ & $56(93.3)$ & 1.37 & $5^{\text {th }}$ \\
\hline Bee ke & $0(0.00)$ & $1(1.7)$ & $0(0.00)$ & $59(98.3)$ & 0.15 & $7^{\text {th }}$ \\
\hline p processing & $16(26.7)$ & $31(51.7)$ & $7(11.7)$ & $6(10.0)$ & 0.03 & $8^{\text {th }}$ \\
\hline Gathering of forest produce & $10(16.7)$ & $27(45.0)$ & 10(16.7) & $13(21.7)$ & 1.95 & $3^{\text {rd }}$ \\
\hline Fish farming & $0(0.00)$ & $0(0.00)$ & $0(0.00)$ & $60(100.0)$ & 1.56 & $4^{\text {th }}$ \\
\hline
\end{tabular}

Source: Field survey 2015. Figures in parentheses are in percentages

\subsection{Level of use of coping strategies}

The results on level of use of both non-agricultural and agricultural based coping strategies as shown in Table 3 indicate by majority $(53.3 \%)$ of the respondents is high. This is normal as people would often engage in activities that profitable than otherwise. Adereti (2005) had earlier noted that rural women are highly involved in both agricultural non-agricultural agricultural activities as measures to cope with poverty.

Table 3: Distribution of respondents on level of use of coping strategies

\begin{tabular}{|c|c|c|c|c|c|c|c|}
\hline \multirow{3}{*}{ Non-agricultural coping activities } & \multirow[b]{3}{*}{ Score } & \multirow[b]{3}{*}{$\mathbf{F}$} & \multirow[b]{3}{*}{$\%$} & \multirow{3}{*}{$\begin{array}{c}\text { Mean } \\
20.2\end{array}$} & \multirow{2}{*}{$\frac{\text { SD }}{9.136}$} & \multirow{2}{*}{$\begin{array}{c}\text { Minimum } \\
5.00\end{array}$} & \multirow{3}{*}{$\frac{\text { Maximum }}{36.00}$} \\
\hline & & & & & & & \\
\hline & & & & & \multirow{6}{*}{2.700} & \multirow{6}{*}{3.00} & \\
\hline Low & $<20.2$ & 28 & 46.7 & \multirow{5}{*}{9.7} & & & \multirow{5}{*}{14.00} \\
\hline High & $\leq 20.2$ & 32 & 53.3 & & & & \\
\hline Agricultural coping activities & & & & & & & \\
\hline Low & $<9.7$ & 28 & 46.7 & & & & \\
\hline High & $\leq 9.7$ & 32 & 53.3 & & & & \\
\hline
\end{tabular}

Source: Field survey 2015 


\subsection{Respondents' constraints to coping strategies}

Constraints to respondents' coping strategies to poverty are shown in Table 4. The results indicate that lack of access to credit facility (70\%), education (55\%), finance (71\%), cost of transportation (56.7\%) and storage facilities posed serious constraints to respondents in their efforts to cope with poverty while access to land (60\%) and socio-cultural restrictions (Purdah) (48.3\%) constituted mild constraints. The results also revealed that lack of access to credit ranked $1^{\text {st }}(\bar{x}=1.67)$ followed by finance $(\bar{x}=1.60)$, cost of transportation $(\bar{x}=1.52)$, education $(\bar{x}=1.43)$ and storage facilities $(\bar{x}=1.08)$ which ranked $2^{\text {nd }}, 3^{\text {rd }}, 4^{\text {th }}$ and $5^{\text {th }}$ respectively.

Table 5 further revealed that the respondents' level of constraints is high (55\%). The result implies that the respondents' level of coping strategy may not strong enough in librating them from the vicious cycle of poverty. Early research findings have also confirmed lack of capital (Oladejo, Olawuyi, and Anjorin 2011), inability to access bank loan, and lack of access to inputs (Damisa, Samndi, and Yohanna 2007, Lawanson, 2008) as factors restricting women in their poverty mitigating efforts.

Table 4: Distribution of respondents on constraints to coping strategies

\begin{tabular}{lccccc}
\hline Variables & Serious & Mild & Not a constraints & Mean & Rank \\
\hline & $\mathbf{F}$ & $\mathbf{F}$ & $\mathbf{F}$ & & \\
\hline Lack of storage facilities & $27(45.0)$ & $11(18.3)$ & $22(36.7)$ & 1.08 & $5^{\text {th }}$ \\
High cost of transportation & $34(56.7)$ & $23(38.3)$ & $3(5.0)$ & 1.52 & $3^{\text {rd }}$ \\
Finance & $43(71.7)$ & $10(16.7)$ & $7(11.7)$ & 1.60 & $2^{\text {nd }}$ \\
Lack of access to land & $7(11.7)$ & $36(60.0)$ & $17(28.3)$ & 0.83 & $6^{\text {th }}$ \\
Lack of education & $33(55.0)$ & $20(33.3)$ & $7(11.7)$ & 1.43 & $4^{\text {th }}$ \\
Lack of access to credit facility & $42(70.0)$ & $16(26.7)$ & $2(3.3)$ & 1.67 & $1^{\text {st }}$ \\
Socio-cultural restrictions(Purdah) & $5(8.3)$ & $29(48.3)$ & $26(43.3)$ & 0.65 & $7^{\text {th }}$ \\
\hline
\end{tabular}

Source: Field survey 2015. Figures in parentheses are in percentages

Table 5: Level of constraints to coping strategies

\begin{tabular}{ccccccc}
\hline Level of constraints faced & F & $\%$ & Mean & SD & Minimum & Maximum \\
\hline Low & 27 & 45.0 & 8.78 & 2.05 & 5.00 & 13.00 \\
High & 33 & 55.0 & & & & \\
\hline
\end{tabular}

Source: Field survey 2015. Figures in parentheses are in percentages

\section{Test of Hypothesis}

\subsection{Relationship between selected socio-economic characteristics of the respondents and poverty coping strategies}

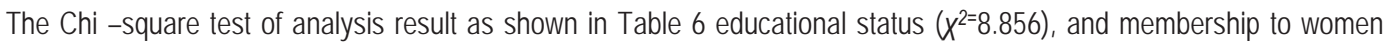
group $\left(X^{2=6.563)}\right.$ were significantly related to respondents' uptake of non- agricultural poverty coping strategies while marital status $\left(X^{2=1.825)}\right.$ religion $\left(X^{2=3.338)}\right.$ and membership to cooperative group $\left(X^{2=0.000}\right)$, were not significantly related to their uptake of non-agricultural poverty coping strategy. This infers that participation in group association and educational status affected respondents' extent of uptake of non-agricultural based poverty coping strategy. The result is consistent with the finding of Fadairo and Sangotegbe (2014) on membership to women group but contradicts the same source on education as a factor on farmers' adoption behavior.

On the other hand, respondents' membership to women group $\left(X^{2=8.929)}\right.$ was found to be significantly related with respondents' uptake of agricultural based poverty coping strategies while marital status $\left(X^{2}=2.746\right)$, educational status $\left(x^{2}=1.741\right)$, religion $\left(X^{2=1.043}\right)$ and membership to cooperative group $\left(X^{2}=2.143\right)$ showed no significant relationship with respondents' uptake of agricultural based coping strategy. The result depicts that respondents who do not belonged to women group associations may not benefit anything therein in coping with poverty. The result agrees with that of Adekoya, Ogunele and Fadairo 2009) who established a positive relationship between membership to associations and adoption of innovation. 
Table 6: Chi-square table showing relationship between respondents' selected socio-economic characteristics and level of coping strategies

\begin{tabular}{lcccccccc}
\hline Variables & \multicolumn{1}{c}{ Non Agricultural coping strategies } & Agricultural coping strategies \\
\hline & $X^{2}-$ value & Df & CC & P & $X^{2}$ - value & Df & CC & P \\
Marital status & 1.825 & 3 & 0.172 & 0.619 & 2.746 & 3 & 0.209 & 0.433 \\
Educational status & 8.856 & 3 & 0.359 & 0.031 & 1.741 & 3 & 0.168 & 0.628 \\
Religion & 3.338 & 1 & 0.230 & 0.068 & 1.043 & 1 & 0.307 & 0.307 \\
Membership of cooperative group & 0.000 & 1 & 0.000 & 1.000 & 2.143 & 1 & 0.186 & 0.143 \\
Membership of women group & 6.563 & 1 & 0.314 & 0.010 & 8.929 & 1 & 0.360 & 0.003 \\
\hline
\end{tabular}

\subsection{Relationship between Age, household size, farm size, farming experience and level of coping strategies used}

The results on Pearson's correlation analysis as shown in Table 7 reveal that enterprise size $(r=-0.276)$, experience $(r=0.381)$, and constraints ( $r=-0.394)$ significantly correlated with respondents' level of use of non-agricultural coping strategies while no significant correlation existed between respondents' age $(r=0.133$ and household size $(r=-0.020)$ and their level use of non-agricultural based coping strategies. In the same vein, farm size $(r=-0.335)$, experience $(r=0.625)$, constraints $(r=-0.423)$ also showed significant correlation with respondents' level of use of agricultural based coping strategies while age $(r=0.173)$ and household size $(r=-0.085)$ did not. This implies that the high the farm size, experience and constraints, the high their effects in mitigating poverty among the respondents. The result contradicts the study of Okoedo-Okojie and Onemolease (2009) which revealed that age and family size influenced the adoption behavior of farmers.

Table 7: PPMC showing relationship between respondents' age, household size, farm size, farming experience and level of coping strategies used

\begin{tabular}{lcccc}
\hline Variables & \multicolumn{2}{c}{ Non Agricultural coping strategies } & \multicolumn{2}{c}{ Agricultural coping strategies } \\
\hline & $\mathbf{r}$ & $\mathbf{p}$ & $\mathbf{p}$ & $\mathbf{p}$ \\
Age & 0.133 & 0.310 & 0.173 & 0.187 \\
Household size & -0.020 & 0.877 & -0.085 & 0.518 \\
Farm size/enterprise size & $-0.276^{*}$ & 0.033 & $-0.335^{\star}$ & 0.009 \\
Experience & $0.381^{*}$ & 0.003 & $0.625^{*}$ & 0.000 \\
Constraints & $-0.394^{*}$ & 0.002 & $-0.423^{\star}$ & 0.001 \\
\hline
\end{tabular}

*Significant relationship @ 0.05 sig. level

\section{Conclusion and Recommendations}

The study concluded that rural women's level of use of both non-agricultural and agricultural poverty coping strategies was high. In addition, level of constraints to poverty coping strategies was high. It is therefore recommended that:

1. A special inputs intervention by Government should be made available to women at subsidized rate to enhance their production efficiency and poverty coping mechanisms.

2. There should be a policy framework targeted at reducing or obliterating the bureaucratic principles that creates barriers to rural women in having access to bank credit or any other sources.

\section{References}

Adato, M., Carter, M.R. and May, J. (2006) Exploring poverty traps and social exclusion inSouth Africa using qualitative and quantitative data. Journal of Development Studies 42 (2), pp. 226-247

Addae-Korankye, A (2014). Causes of Poverty in Africa: A Review of Literature. American Journal of Social Sciences. 3(7), 147-153

Adekoya, A.E., Ogunnele, A.O \& Fadairo, O.S. (2009). Awareness and Use of Information Communication Technologies among Cattle Rearers in Oke-Ogun Area of Oyo State, Nigeria. Journal of Technology and Education in Nigeria. 14, 1\&2, 21-28

Adereti, F.O. (2005). Coping mechanisms of rural women in poverty alleviation in osun state In a democratic and deregulated economy: implications for agricultural Extension as a discipline in Journal of Agricultural Extension, 8

Akeweta J., Oyesola O.B, Ndaghu A and Ademola A.O (2014). Social Capital and Poverty Coping Strategies of Rural Women in Song Local Government Area of Adamawa State, Nigeria. Nigerian Journal of Rural Extension and Development 8, 1-8

Alayande, B \&. Alayande, O (2004). A quantitative and qualitative assessment of vulnerability to poverty in Nigeria. Being paper 
submitted for presentation of CSAE Conference on poverty reduction, growth and human development in Africa, March.

Anyanwu, J.C (1997). Poverty in Nigeria: Concepts, Measurement and Determinants. In O. Teriba (ed.), Poverty Alleviation in Nigeria. Ibadan: Nigerian Economic Society, 1997.Babatunde, R. A.

Apata, T.G., Apata, O.M., Igalajobi, O.A \& Awoniyi, S.M.O (2010). Determinants of Rural Poverty in Nigeria: Evidence from Small Holder Farmers In South- Western, Nigeria. Journal of Science and Technology Education Research, 1(4), 85-91.

Armstrong, P, Lekezwe, B \& Siebrits, K. (2010). 'Poverty Remains the Priority for South Africa. (online) available (May 20, 2015)

Asogwa, B.C., Umeh, J.C \&Okwoche, V.A. (2012). Poverty and Efficiency among the Farming Households in Nigeria: A Guide for Poverty Reduction Policy, Current Research Journal of Economic Theory, 4(1), 6-10.

Ayoola, G.B, Aina, B., Mamman, A., Nweze, N., Odebiyi, T., Okunmadewa, F., Shehu, D., Williams, O \& Zasha, J (2000). Nigeria: Voice of the Poor; Country Synthesis Report World Bank.

Barrett, C.B., Marenya, P.P., Mcpeak, J., Minten, B., Murithi, F., Oluoch-Kosura, W., Place, F., Randrianarisoa, J.C., Rasambainarivo, J. and Wangila, J. (2006) Welfare dynamics in rural Kenya and Madagascar. Journal of Development Studies 42(2), pp. $248-277$.

Carter, M.R., Little, P.D., Mogues, T. and Negatu, W. (2007) Poverty Traps and Natural Disasters in Ethiopia and Honduras. World Development, 35(5), pp. 835-856.

Damisa, M.A, Samndi, J.R, and Yohanna, M. (2007). 'Women Participation in Agricultural Production: A probit analysis', Journal of Applied sciences, 7 (3), 412-414

Duyilemi, O.P., Adegbite, R.A., Abiola, J.K \& Onawumi, O.A (2008). Role of women in Agricultural Development in four selected communities in Oyo State, Nigeria. Proceeding of the First national Conference of the Society for Gender in Agriculture and Rural Development. 188

Edeoghon, C.O \& Koyenikan, M.J. (2010). Poverty coping mechanisms of rural women in Ehime, Mbano Local Government Areas of Imo State, Nigeria: implications for globalization. Nigeria journal of Rural Sociology, 10, 1, 25-31

Ekpe, A. E (2011). Poverty Alleviation in Nigeria through Capitalism Economic Framework: Problems and Challenges. Journal of sustainable Development in Africa, Pennsylvania: Clarion University of Pennsylvania

Etim, N.A. and Edet, G.E (2007). Determinants of Rural Poverty among Broiler Farmers in Akwa Ibom State. In Proceedings of the Nigerian Society for Animal Production on Sustainability of the Livestock Industry in an Oil Economy. Calabar: NSAP, 410-411

Ezebuiro, N.C., Ironkwe, A.G., Ugboaja, C.I, \& Okoro, B.O (2010). Adoption of Improved Cassava Varieties by Women in Umuahia Agricultural Zone of Abia State, Nigeria, Nigeria journal of Rural Sociology 10 (1) 56-61

Fadairo, O.S \& Sangotegbe, N.S (2014). Awareness and Uptake of the national Farm Inputs and Food production Policy among Arable Crop Faemers in Ogun State, Nigeria. Nigerian Journal of Rural Extension and Development 8

Federal Office of Statistics (FOS) 1999. Poverty profile for Nigeria 1980-1996, Abuja: Federal Office of Statistics

Hunter-Gault, C (2006) Land ownership Elusive in South Africa's Poor. www.npr.org/2006/08/7/5624419/land-ownership-elusive-forsouth-Africa-poor/accessed 04/09/2015

Ironkwe, A.G, Asiedu, R., Chinaka, E.C., \& Ezebuiro, C.N. (2008). Comparative Analysis of Women's Invovement in Crop Production in Ohafia and Umuahia Agricultural zones of Abia State, Nigeia. Proceeding of the Seventeeth Annual Congress of NRSA. 70

Janowski, M (2003). Rural non-farm livelihood Activities in Romania, Georgia And Armenia: synthesis of Findings from fieldwork carried out at village level 2001-2002. UK Natural Resources Institute, University of Greenwich

Jibowo, A.A and Ajayi, A.O. (2011). History of Agricultural Extension in Nigeria. In (ed) AESON.Illorin: Agricultural Extension Society of Nigeria.

Lawanson, O.I. (2008). Female labour force participation in Nigeria:'Determinants and Trends', Oxford Business and Economic Conference Program, Oxford, United Kingdom. June 22-24.

Lybbert, T.J., Barrett, C.B., Desta, S. and Coppock, D.L. (2004) Stochastic Wealth Dynamics and Risk Management among a Poor Population. The Economic Journal, 114(498), pp. 750-777.

Maina, Z (2013).Nigeria women are living below poverty line (online) available.http://dailypost.ng/2013/07/13/70-of-nigerian-women-areliving-below-poverty-line-minister/accessed (May 21, 2015)

Moghadam V. (2005), Globalizing Women: Transitional Feminist Network. Social and Human Sciences (SHS) Papers in Women's Studies / Gender Research Work, No 2, pp 4-6, 13-23.

National Bureau of Statistics (NBS) (2005). Poverty Profile for Nigeria. Abuja: National Bureau of Statistics

National Bureau of Statistics (NBS) (2007). Nigeria Poverty Assessment 2007. The National Bureau of Statistics in Collaboration with the World Bank.

National Bureau of Statistics (NBS) (2009). (online) available www.nigerianstat.gov.ng. (May 21, 2015)

National Bureau of Statistics (NBS) (2010). Harmonized Nigeria Living Standard Survey.

National Population Commission (NPC) (2006). Population and housing census of Federal Republic of Nigeria, Kogi State

Nigeria Observer (2014). Population Census in Nigeria. http://www.nigerianobservernews.com/2014/12/09/population-census-inNigeria/23/08/2015

Obadan, N.I (2002). Poverty reduction in Nigeria, The way Forward. CBN Economic and Financial Review, 39(4)

Okoedo-Okojie, D.U \& Onemolease, E.A (2009). Factors Affecting the Adoption of yam Storage Technologies in the Northern Ecological Zone of Edo State. Nigeria Journal of Human Ecology, 27 (2)

Okunmadewa, F (2002). Poverty and Agricultural Sector. Poverty reduction and the Agricultural sector in Nigeria, edited by Foluso Okunmadewa, Elshaddai Global Ventures Ltd. Ibadan, Nigeria.

Okunmadewa, F 2005. The World Bank and Poverty Reduction programmes in Nigeria: An Overview. Nigeria Journal of Rural 
Sociology,5(1\&5): 1-6

Okunmadewa, FY, Yusuf, S.A \&Omonona, B.T (2005). Social Capital And Poverty Reduction in Nigeria, Revised Report Submitted To Africa Economic Research Consortium (AERC) Nairobi, Kenya.

Oladejo, J.A., Olawuyi, S. O and Anjorin, T. D (2011). Analysis of Women Participation in Agricultural Production in Egbedore Local. International Journal of Agricultural Economics and Rural Development (4) 1

Olawoye J.E 2003. Food security and Rural Development in a Deregulated Economy. In (eds) Ladele A.A and Ogunwale A.B Proceedings of $13^{\text {th }}$ Annual Conference of The Nigerian Rural Sociological Association. $26^{\text {th }}-28^{\text {th }}$ November, 1-6

Oluwatayo, I.B (2014). Gender Dimensions of Poverty and Coping Options among Smallholder Farmers in Eastern Nigeria. Mediterranean Journal of Social Sciences, 5 (27)

Oluwatoyin, D. A (2013). Women and Poverty Alleviation Programmes in Nigeria: The Napep Approach Academic Journal of Interdisciplinary Studies 2(3), 515-521

Omoniyi, V.A (2012). Policy Implementation and Rural Poverty Reduction in Nigeria: An Analysis of NAPEP in Ado Odo Ota Local Government, Ogun State. A Thesis Proposal Submitted to the Department of Political Science, Faculty of Social Science, in Partial Fulfillment for the award of Ph.D Degree in Political Science, March 29, 2012

Sen C 1985. Women and Development Laborers; Regional variations in incidence and Employment" In Tyranny of the households Investigative Essays on Women's works (eds) Deriki, J and Bannerjee. New Delhi, Shata Publishers, 108-121

Simpa, J.O (2014). Poverty Determinants among Female-Headed Household Rural Farmers in Nasarawa State, Nigeria PAT 10 (1): 93109 available at www.patnsukjournal.net/currentissue/ accessed 25/06/2015

U.N (1990). World survey on the role of women in development. Geneva: Department of International and Social Affairs 12

UNDP (1997). Human Development Report. New York: Oxford University press Webster new World Dictionary of the American Language (1984). New York: Simon and Schuster

UNDP Nigeria (1998). Nigeria-Human Development Report. Lagos: United Nations Development Programme

Vincent, A.Y. (2006) Challenges of MDGS and Imperative of Globalization. Daily Trust Friday, October 6, 2006 Pp14.

World Bank (2005a) African Development Indicators 2005. New York :Oxford University Pres

World Bank (2006). Kenya Inside Informality: Poverty, Jobs, Housing and Services in Nairobi's Slum. Washington D.C: Water and Urban Unit 1, Africa Region. 122

World Bank (2009). Mozambique - sixth poverty reduction support credit program, IDA, World Bank, Washington DC.

World Bank (2010). World Bank Updates Poverty Estimates for Developing World in a divided world. Pal grave Macmillan. http://econ.worldbank.org

World Bank, (2000) Poverty and welfare in Nigeria in Collaboration with Federal Office of Statistics and National Population Commission, Nigeria, Lagos: Impact Press

Yahaya, M \& Olowu, $T$ (1998). An Assessment of the Socio-Economic Profile of Women Farmers in North-Central Nigeria. Lesson from Rural Planning. Nigeria Journal of Rural Sociology. 2, 56-61 